\title{
Financial Decision, Innovation, Profitability and Company Value: Study on Manufacturing Company Listed in Indonesian Stock Exchange
}

\author{
Mursalim, Hendragunawan, Nur Alamzah, Abdullah Sanusi \\ University of Hasanuddin, Makassar, Indonesia \\ mursalim1906nohong@gmail.com
}

\begin{abstract}
This study aims to describe the relationship between financial decisions, innovation, enterprise profitability and the value of the company. Based on the research objectives, this research is a causality research. The data used are secondary data for a 5-years period, obtained through several sources such as Indonesian Capital Market Directory (ICMD) and the websites of 22 companies. The results show that (1) Investment decision affects company profitability positively and significantly, (2) Investment decision affects company value positively and significantly, (3) Capital structure affects company profitability positively and significantly, (4) Capital structure affects company value positively and significantly, (5) Dividend policy affects company profitability positively and significantly, (6) Dividend policy does not affect company value, (7) Innovation affects company profitability positively and significantly, (8) Innovation affects company value positively and significantly, and (9) Profitability affects company value positively and significantly.
\end{abstract}

Keywords: Financial Decision, Innovation, Profitability, Company Value

\section{Introduction}

Firm's value is very important. Value can be perceived as a management success in managing the company. Value also reflected market response to the company. Stakeholder theory explains that the increase in the value of the company which can be measured by the share price that showed shareholder wealth. Hendri (2010) asserts that the firm's value is a reflection of the market value the firm. Therefore, the higher the value of the stock market, the higher the value of the company that will influence the firm's share. The higher the demand for the firm's shares, the higher the value of the firm. The scholars in financial study have yet to agree in several things related to firm's value. Some researchers argue that the value of a firm is influenced by its antecedents (Wesley et al., 2014) while other scholars argued that the value of the firm is the antecedents itself as conducted by Cho (1998). The results research of Geroski et al., 1993; Leiponen, 2000; Cefis and Ciccarelli, 2005 found that there is a link between innovation and value creation and Profit Corporation (Belenzon and Patacconi, 2013). Maximizing the value of the company require optimal effort from a manager. Therefore, a manager is required to make decisions careful and integrated decisions. Accuracy is very crucial in decision making, especially financial decisions such as investment decisions, funding decisions and dividend decision (Van Horne and Wachowizs, 2009). Certain financial decision will affect other financial decisions and the impact on the value of the company (Fama and French, 1998).

Decision regarding innovation also has a significant role on the performance of the firm, especially for creating competitive advantage of the firm. Porter (1990) explains that the company that owns the competitiveness is a company that has the advantage over the average industry. Solanas in Sujono (2010) emphasizes the importance of innovation not only for the firm but also to the economic competitiveness of a country. Innovation is defined as the development and use of new ideas or behavior within the organization. This study aims to describe (1). The influence of financial decisions and innovations on the profitability of the firm, and (2).The influence of financial decisions and innovation on firm's value.

\section{Literature Review}

Van Horne and Wachowicz (2009) differentiate that there are three types of financial decisions in the firm, namely investment decisions, financing decision and dividend decisions. Determination and a right combination of the three decisions will have a significant impact on the performance and the value of the firm. The output of an innovation is related to the firm's performance and the expenditure incurred. The growth in total sales is affected by the innovation that occurred in the firm (Kemp et al., 2003). Improving firm's performance is one of the main reasons firms choose to innovate. Innovation could be in the form 
of increasing demand or cost reduction. New product or process can be a source of market advantage for inventors. Companies can increase demand through product differentiation by creating new markets and affect demand for existing products. Innovation can also improve the performance of the company in the form of increased profitability derived from the assets or equity owned. In addition, performance can also be obtained through increased production process capabilities that enable companies to develop a wide range of new products (Sujono, 2010). High profitability shows good prospects for the company, which signaled positively to the prospective investors (Sujoko and Soebiantoro, 2007). The value of the firm is often defined as the market value since the increasing price of stock indicates the wealth of the shareholders. The value of the company is reflected in the accounting data in the financial statements (Ohlson, 1995; Callen and Segal, 2005). The value of public firms showing indicated by the value of all assets and also reflected in the market value. Therefore, the higher the stock price the higher the value of the firm.

\section{Methodology}

For this study, data was obtained from Indonesian Stock Exchange (BEI), specifically characterized as:

- Firm which shown profit

- Explicitly indicate Research and Development expense in its statement

- Publicly report stock price during the period of the study

- Dividend paid annually for the period of the study

Based on these criteria, we identified 13 firms during a 6-year observation period (2008-2013). The data were analyzed using inferential statistics using Structural Equation Modeling (SEM) variance-based method known as Partial Least Square (PLS).

\section{Figure 1: Conceptual Framework}

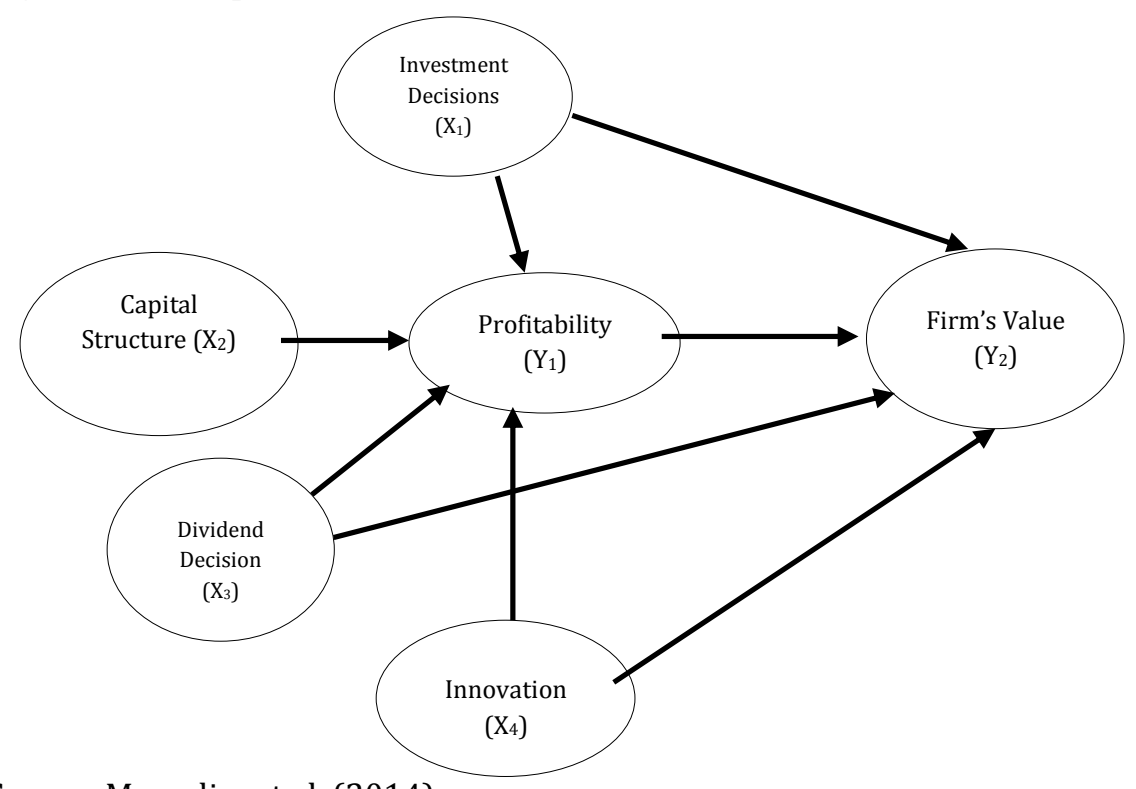

Source: Mursalim et al. (2014)

Based on this conceptual framework, we hypothesized that:

- The higher the investment made by the company the higher profitability and value of the firm

- The more effective the financial decision (capital structure) the higher the profitability and the value of the firm

- The higher the dividend paid by the firm to its shareholders the higher the profitability and the value of the firm

- The higher the innovation the higher profitability and the value of the firm

\section{Results}

Linearity Test: Table 1 below shows the assumptions of curve fitting linearity performed with SPSS software where we employed parsimony principle such as (1) where significant linear model, or (2) when 
the whole model is perhaps the non-significant. Specification of the model used as the basis for testing is a linear model, quadratic, cubic, inverse, logarithmic, power, S, compound, growth and exponential. The two principles above indicate linearity assumptions are met.

Table 1: Linearity Test

\begin{tabular}{|c|c|c|}
\hline Indication & Result & Notes \\
\hline Investment decision to profitability & $\begin{array}{l}\text { Significant linear model } \\
\text { (Sig Linier } 0.000<0.05 \text { ) }\end{array}$ & Linier \\
\hline Investment to firm's value & $\begin{array}{l}\text { Model Linier Signifikan } \\
\text { (Sig Linier } 0.000<0.05 \text { ) }\end{array}$ & Linier \\
\hline Capital structureto Profitability & $\begin{array}{l}\text { Model Linier Signifikan } \\
\text { (Sig Linier } 0.000<0.05 \text { ) }\end{array}$ & Linier \\
\hline Capital structureto firm's value & $\begin{array}{l}\text { Model Linier Signifikan } \\
\text { (Sig Linier } 0.000<0.05 \text { ) }\end{array}$ & Linier \\
\hline Dividend decisionto profitability & $\begin{array}{l}\text { Model Linier Signifikan } \\
\text { (Sig Linier } 0.000<0.05 \text { ) }\end{array}$ & Linier \\
\hline Dividend to firm's value & $\begin{array}{l}\text { Model Linier Signifikan } \\
\text { (Sig Linier } 0.000<0.05 \text { ) }\end{array}$ & Linier \\
\hline Innovation to profitability & $\begin{array}{l}\text { Model Linier Significant } \\
(\text { Sig Linier } 0.000<0.05 \text { ) }\end{array}$ & Linier \\
\hline Innovation to firm's value & $\begin{array}{l}\text { Model Linier Significant } \\
\text { (Sig Linier } 0.000<0.05 \text { ) }\end{array}$ & Linier \\
\hline Profitability to firm's value & $\begin{array}{l}\text { Model Linier Significant } \\
\text { (Sig Linier } 0.000<0.05 \text { ) }\end{array}$ & Linier \\
\hline
\end{tabular}

Source: Mursalim et al. (2014)

\section{Goodness of Fit Model:}

- The measurement of variable profitability, obtained $\mathrm{R}^{2}$ as 0.727 or $72.7 \%$.This indicates that $72.7 \%$ company profitability affected by an investment decision, capital structure, dividend decision and innovation.

- The measurement of variable company value, obtained $\mathrm{R}^{2}$ as 0.826 or $81.6 \%$. This indicates that $81.6 \%$ of company value affected by an investment decision, capital structure, dividend decision and innovation. Thus value predictive relevance ( q2 ) obtained as follows:

$\mathrm{Q} 2=1-\left(1-\mathrm{R}_{1}^{2}\right)\left(1-\mathrm{R}_{2}{ }^{2}\right)$

$\mathrm{Q} 2=1-(1-0.727)(1-0.816)$

$\mathrm{Q} 2=0.9496$

The result of calculation shows the value of predictive-relevance 0.9496 or $94.96 \%$ worth very high, so that the model is said to have predictive value worthy relevant.Predictive value relevance of $94.96 \%$ indicates that the variation in the data that can be described by models PLS is built as much as $94.96 \%$ or In other words the information contained in the data $94.96 \%$ can be explained by the model. While the rest $5.04 \%$ described by other variables ( who had not contained in the model and error.

\section{The calculation results of inner model of direct effect variable:}

Table 2: The calculation results of inner model of direct effect variable

\begin{tabular}{lllll}
\hline $\begin{array}{l}\text { Direct } \\
\text { Effect }\end{array}$ & $\begin{array}{l}\text { Inner } \\
\text { Weight }\end{array}$ & T-statistik & P-value & Notes \\
\hline X1 -> Y1 & 0.114 & 2.023 & 0.043 & Significant \\
X1 -> Y2 & 0.148 & 2.913 & 0.004 & Significant \\
X2 -> Y1 & 0.492 & 10.859 & 0.000 & Significant \\
X2 -> Y2 & 0.284 & 4.708 & 0.000 & Significant \\
X3 -> Y1 & 0.574 & 10.246 & 0.000 & Significant \\
X3 -> Y2 & 0.074 & 1.068 & 0.286 & Insignificant \\
X4 -> Y1 & 0.135 & 2.399 & 0.016 & Significant \\
X4 -> Y2 & 0.235 & 5.452 & 0.000 & Significant \\
Y1 -> Y2 & 0.542 & 11.173 & 0.000 & Significant \\
\hline
\end{tabular}

Source: Mursalim et al. (2014) 
From the table above test results, it shows that:

- The test on investment decision related to profitability shows that inner weight coefficient value is 0.114 , with t-test 2.023 , and p-value of 0.043 . The test results indicate that there is a significant direct effect on the profitability of the investment decision. The positive inner weight coefficient indicates positive relationship, which means that the higher the investment decision the higher profitability will be.

- The test on the influence of investment decision to the value the firm shows that, the value of the coefficient of the inner weight is 0.148 , with t-statistics for 2.913 , and the p-value of 0.004 . The results indicate that there is a significant direct effect between investment decisions to the firm's value. Inner coefficient is positive weight indicates that relationships are both positive. Therefore, the higher the investment decision the higher the value of the firm.

- The test on the influence of Capital Structure on Profitability, we compute that the inner weight coefficient is 0.492 , with t-test 10.859 and p-value of 0.000 . It indicates that there is a significant direct effect of capital structure on profitability. The inner weight coefficient value is positive which is indicating that the relationship is positive. Therefore, the higher the capital structure the higher the profitability.

- Test on direct effect of capital structure on company value, our calculation showed that the inner weight coefficient of 0.284 , with a value of T-statistics for 4.708 , and the p-value of 0.000 . The results indicate that there is a significant direct effect of capital structure on company value. Therefore, the higher the capital structure the higher the value of the company.

- Testing the direct influence of Dividend Policy on profitability, the value of the inner weight coefficient of 0.574 , with a value of $10246 \mathrm{~T}$ - statistics and p -value of 0.000 . The test results indicate that there is a significant direct effect on the profitability of dividend policy. Inner weight coefficient is positive indicates that relationships are both positive. That is, the higher the dividend policy, will result in the higher profitability.

- Test on direct effect of dividend decision on profitability, our calculation showed that the inner weight coefficient of 0.074 , with a value of T-statistics for 1.068, and the p-value of 0.286 . There was no significant direct influence between dividend policies of the company. That is, the higher the low Dividend Policy, will not result in the high or low values of the company.

- Testing the direct influence of innovation for profitability, inner weight coefficient values obtained for 0.135 , with the value of T-statistics for 2.399 , and the $\mathrm{p}$-value of 0.016 .The test results indicate that there is a significant direct effect of innovation on profitability. Inner weight coefficient is positive indicates that relationships are both positive. That is, the higher Innovation, will result in the higher profitability.

- Testing the direct influence of innovation on company value, the value of the inner weight coefficient of 0.235 , with a value of -statistics for 5.452, and the p-value of 0.000 . The test results indicate that there is a significant direct effect of innovations on company value. Inner coefficient is positive weight indicates that relationships are both positive. That is, the higher Innovation , will lead to higher the value of the company.

- Testing the direct influence between the profitability on company value, the value of the inner weight coefficient of 0.542 , with a value of 11.173 , T- statistic and p -value of 0.000 . The test results indicate that there is a significant direct influence between the profitability of the company value. Inner coefficient is positive weight indicates that relationships are both positive. That is, the higher profitability, will lead to higher the value of the company.

The calculation results of inner model of indirect effect variable: From the above test results, it can be concluded that:

- Indirect effect between investment decisions on the value of the company, through the intermediary of profitability obtained a coefficient of 0.062 . Both the direct effect that the investment decision to profitability significant, and the profitability of the company value significantly, then the indirect effect of investment decisions on the value of the company through an intermediary profitability is significant. Thus, the higher the investment decisions that will push deficits improve profitability, the higher the company value.

- The indirect effect of capital structure on company value, through the intermediary of profitability, obtained by the coefficient of 0.266 . Both the direct effect that the capital structure to profitability significant, and the profitability of the company's value significantly, then the indirect effect of capital structure on company value, through profitability is significant . By him it can be said that the higher the capital structure, the higher the profitability and indirectly will result in higher the value of the company 
The indirect effect of dividend policy on company value, through the intermediary of profitability, obtained by the coefficient of 0.311 . Both the direct effect that the dividend policy of the profitability significant, and the profitability of the company value significantly, then the indirect effect of dividend policy on the company value, through the intermediary of profitability is significant. Thus the higher the dividend policy that will improve the profitability and indirectly will result in higher the value of the company.

Table 3: The calculation results of inner model of indirect effect variable

\begin{tabular}{|c|c|c|c|}
\hline Indirect effect & $\begin{array}{l}\text { Testing } \\
\text { Direct effect1 }\end{array}$ & Direct effect 2 & Notes \\
\hline $\begin{array}{l}\mathrm{X} 1->\mathrm{Y} 2 \\
\text { mediate of Y1 } \\
\text { Coefficient: } \\
0.114 \times 0.542=0.062\end{array}$ & $\begin{array}{l}\text { X1 -> Y1 } \\
\text { Coefficient } 0.114 \\
\text { Significant }\end{array}$ & $\begin{array}{l}\text { Y1 -> Y2 } \\
\text { Coefficient } 0.542 \\
\text { Significant }\end{array}$ & Significant \\
\hline $\begin{array}{l}\mathrm{X} 2->\mathrm{Y} 2 \\
\text { mediate of Y1 } \\
\text { Coefficient: } \\
0.492 \times 0.542=0.266\end{array}$ & $\begin{array}{l}\mathrm{X} 2 \text {-> Y1 } \\
\text { coefficient: } 0.492 \\
\text { Significant }\end{array}$ & $\begin{array}{l}\text { Y1 -> Y2 } \\
\text { Coefficient } 0.542 \\
\text { Significant }\end{array}$ & Significant \\
\hline $\begin{array}{l}\mathrm{X} 3 \text {-> Y2 } \\
\text { mediate of Y1 } \\
\text { Coefficient: } \\
0.574 \times 0.542=0.311\end{array}$ & $\begin{array}{l}\text { X3 -> Y1 } \\
\text { coefficient: } 0.574 \\
\text { Significant }\end{array}$ & $\begin{array}{l}\text { Y1 -> Y2 } \\
\text { Coefficient } 0.542 \\
\text { Significant }\end{array}$ & Significant \\
\hline $\begin{array}{l}\mathrm{X} 4 \text {-> Y2 } \\
\text { mediate of Y1 } \\
\text { Coefficient: } \\
0.135 \times 0.542=0.073\end{array}$ & $\begin{array}{l}\text { X4 -> Y1 } \\
\text { coefficient: } 0.135 \\
\text { Significant }\end{array}$ & $\begin{array}{l}\text { Y1 -> Y2 } \\
\text { Coefficient } 0.542 \\
\text { Significant }\end{array}$ & Significant \\
\hline
\end{tabular}

Source; Mursalim et al. (2014)

Discussion: Enthusiasm from shareholders on the company is indicated by the increase of the stock price. The trend that shows the increasing price of share means positive response from the investors. Positive developments in stock prices and also the positive response from investors as mentioned in signaling theory (Bhattacharya, 1979) is a 'good news' although such phenomenon of good and bad news is more widely discussed previously only in the concept of dividend companies. Our findings indicated that the investment decision, financing and dividend positively influence company value. These results support the research conducted by Afzal and Rohman (2012). In addition, these findings also reinforce the enactment of the concept that has been developed by Brigham and Houston (2001) regarding the effect of the investment policy, funding policy and dividend policy on company value (Brigham and Daves, 2007). Therefore it can be said that in order to increase the value of the company, the company is required to carefully select investment allocation. To gain more optimal value added, the cost of capitalfrom internal and external sources of funding- should be valued less than return of investment (ROI). The decision to use the funds should be within the framework of increasing profitability and value the firm. The choice between the use of debt or equity and a combination of both also need to be carefully considered (Tirole, 2006).

We also found that dividend policy in this study had no significant effect on company value. It means that investors do not consider it as a major consideration to the manufacturing company. Therefore, the results of this study do not strengthen the enactment of signaling theory on manufacturing companies in Indonesia during the period of 2008-2013. These results echoed studies by Sofyaningsih and Pancawati (2011), Christiana and Sugeng (2013). The company's ability to earn a return on assets and equity will be help increasing the value of the company. Our findings showed that using market to book value and Tobins' $Q$, we found that the higher the profitability the higher the value the company. Therefore, we argue that the level of profitability of the firm is a main consideration for potential investors to determine its decision on investing to a firm. The results of this study support previous researches conducted by Hermuningsih (2013), Chen and Chen (2011), and Naceur and Goaied (2002).

Brigham and Daves (2007) argued that a firm generates sales, pays its costs and taxes, and makes the necessary investments in assets to support its growth. All investments activities are reported to the investors in the form of financial report. The firm's capital structure and the risk of its operations indicate as a risk of the free cash flows to the investors. This risk is combined with the level of interest rates in the 
economy and investors' overall behavior toward risk. Innovative companies will face different risks compare to other companies. Innovation related to the ability of the company to take advantage of the changes that occur in their environment. Most investors prefer companies that have consistent innovation attitudes. Investors usually responded positively to the firm which shown innovative actions which to some extent influence the profitability of the firm. Therefore, we argued that innovation has a positive and significant effect on company value. These findings support the research conducted by Belenzon and Patacconi (2013) and Berzkalne and Zelgalve (2014).

\section{Conclusion}

From our study, we can conclude that: (1) Investment decision positively and significantly affects company profitability, (2) Investment decision positively and significantly affects company value, (3) Capital structure affects company profitability, (4) Capital structure positively affects company value, (5) Dividend policy positively affects company profitability, (6) Dividend policy does not affect company value, (7) Innovation positively and significantly affects company profitability, (8) Innovation positively and significantly affects company value, and (9) Profitability affects company value. For future studies, we recommend: (1). Research on the relationship between investment decision on innovation, (2). Expand the object of the study to other industries apart from manufacturing sector in our study. (3). Connecting the decision with any other financial decisions.

\section{References}

Afzal, A. \& Rohman, A. (2012). Effect of investment decision, financing decision, and dividend decision on corporate value. Diponegoro Journal of Accountancy, 1(2).

Belenzon, S. \& Patacconi, A. (2013). Innovation and company value: An investigation of the changing role of patents, 1985-2007. Research Policy, 42(8).

Berzkalne, I. \& Zelgalve, E. (2014). Innovation and company value: Evidence from the baltic countries. Regional Formation and Development Studies, 11(3).

Bhattacharya, S. (1979). Imperfect information, dividend policy, and the bird in the hand fallacy. The Bell Journal of Economics, 10(1), 259-270.

Brigham, E. F. \& Daves, P. R. (2007). Intermediate Financial Management. Ninth Edition. Thomson/SouthWestern

Brigham, E. F. \& Houston, J. F. (2001). Fundamentals of Financial Management, Ninth Edition, Horcourt College, United States of America

Callen, J. L. \& Segal, L. (2005). Empirical Tests of the Feltham-Ohlson (1995) Model. Review of Accounting Studies, 10, 409-429.

Cefis, E. \& Ciccarelli, M. (2005). Profit differentials and innovation. Economics of Innovation and New Technology, 14, 43-61.

Christiana, D. \& Sugeng, W. (2013). The Effectivity of Internal and External Corporate Governance Mechanisms Towards Corporate Performance. Research Journal of Finance and Accounting, 4(4), 132-139.

Chen, L. J. \& Chen, S. Y. (2011). Influence the profitability of the enterprise value of the capital structure as a mediator and company size and industry as a moderator. Investment Management and Financial Innovations, 8(3), 121-129.

Cho, M. H. (1988). Ownership structure, investment, and the corporate value: an empirical analysis. Journal of Financial Economics, 47, 103-121

Fama, E. F. \& French, K. R. (1998). Value versus Growth: The International Evidence. The Journal of Finance, 3(6).

Geroski, P., Van Reenen, J. \& Walters, C. F. (1993). How persistently do firms innovate? Research Policy, 26, 33-48

Hendri, R. G. (2010). Factors that encourage creation corporate values in Indonesia stock exchange. Buletin Ekonomi, 8(2), 70-170

Hermuningsih, S. (2013). Effect of Profitability , Growth Opportunity, Structure Against Capital Company Values In Public Company in Indonesia. Buletin Ekonomi Moneter dan Perbankan, 1, 127 - 148

Kemp, R. G. M., Folkeringa, M., de Jong, J. P. J. \& Wubben, E. F. M. (2003). Innovation and firm performance. Research Report. Scientific Analysis of Entrepreneurship and SMEs

Leiponen, A. (2000). Competencies, innovation and profitability of firms. Economics of Innovation and New Technology, 9, 1-24. 
Naceur, S. B. \& Goaied, M. (2002). The relationship between dividend policy,financial structure, profitability and firm value. Applied Financial Economics, 12, 843-849.

Ohlson, J. A. (1995). Earnings, Book Values, and Dividends in Security Valuation. Contemporary Accounting Research, 11, 661-687.

Porter, M. E. (1990). What is National Competitiveness? Harvard Business Review, 68(2), 84-85

Sofyaningsih, S. \& Hardiningsih, P. (2011). Ownership Structure, Dividend Policy, Debt Policy and Corporate Values. Dinamika Keuangan dan Perbankan, 3(1), 68-87.

Sujoko, K. \& Soebiantoro, U. (2007). Effect of Shareholding Structure, Leverage, Internal and External Factors Against company value. Journal of Management and Enterpreneurship, 9(1), 41-48

Sujono, K. (2010). Determinants of Capital Structure, Innovation and Company value. Dissertation of Program of Doctor and Science Management, Brawijaya University, Malang .

Tirole, J. (2006). The Theory of Corporate Finance. British Liberary Cataloguing in Publication Data.

Van Horne, J. C. \& Wachowicz, J. M. Jr. (2009). Fundamentals of Financial Management. Financial Times Press.

Wesley, O. N., Egessa, R. \& Musiega, D. (2014). Corporate diversification as a determinant of firm value: A case of munias sugar manufacturing firm in Kenya. International Journal of Innovative Research and Development, 3(5), 553-561. 